Brit. J. vener. Dis. (1957), 33, 18.

\title{
PRELIMINARY REPORT ON A COMPLEMENT-FIXATION TEST FOR TREPONEMATOSIS (TWR)* $\dagger$
}

\author{
BY \\ I. N. ORPWOOD PRICE AND M. J. WHELAN \\ V.D. Reference Laboratory (M.R.C.), London Hospital Research Laboratories, Whitechapel, London
}

Since 1906, in Wassermann's time, few workers except Tuttle and DeBerry (1955), Magnuson and Portnoy (1956) and Portnoy and Magnuson (1955, 1956) seem to have studied the possibilities of the use of a specific treponemal antigen for use in a complement-fixation test for treponematosis.

The former investigators came to the conclusion that to use an antigen prepared as a "flocculated" treponemal suspension yielded entirely unpredictable results, and that preliminary treatment of the treponemal suspensions with a lipid solvent, such as ether, was essential. Portnoy and Magnuson carried this technique a stage further and, after discarding various lipid fractions, extracted an active principle with a solution of sodium desoxycholate, sodium citrate, and sodium chloride. From a practical angle this antigen seems to have three disadvantages:

(1) The preparation is difficult and lengthy.

(2) The stability of the antigen appears to be limited ( 2 months if stored at $-20^{\circ} \mathrm{C}$.).

(3) The yield of antigen per rabbit was sufficient for only fifty qualitative tests.

The following report gives a brief account of the experiences of the authors whilst producing and testing an antigen made from virulent Treponema pallidum for use in the serological diagnosis of syphilis. After production and checking of the antigen, some 3,279 unselected serial sera were tested in parallel with the standard Wassermann reaction (WR). Of these, 1,030 came from the Whitechapel Clinic, London Hospital, and 1,205 from general hospitals, and 1,044 were problem sera sent into this laboratory for investigation. For evaluation of specificity it was possible to extract 503 antenatal sera from the general hospital group and also 785 sera from the problem group on which treponemal immobilization tests (TPI) had also been performed.

The complement-fixation technique employed has already been described by one of us (Price, 1949), but in order to conserve the antigen, the standard

\footnotetext{
* Received for publication January 29, 1957.
}

t Treponemal Wassermann Reaction. volume adopted was $0.022 \mathrm{ml}$, and to facilitate the readings an extra volume of saline was added to each tube.

\section{Method of Obtaining the Treponemal Antigen}

After several unsuccessful experiments had been made, the following technique was found to yield a sensitive and specific antigen for use in this complement-fixation test.

A rabbit was inoculated intratesticularly with living pathogenic Treponema pallidum (Nichols strain) and the infection allowed to proceed until a firm orchitis was produced ( 5 to 10 days), when the rabbit was killed and the testicles removed with aseptic precautions. The testicles were then sliced along the long axis, fimbriated, and transferred to a flask containing $40 \mathrm{ml}$. of 0.1 per cent. sodium azide in normal saline, and extraction of the treponemata was effected by shaking the flask for $1 \mathrm{hr}$ on a Kahn shaker at approximately 280 oscillations per min. The fluid was then carefully decanted into $25-\mathrm{ml}$. screw-capped bottles and another $40 \mathrm{ml}$. of azided saline added to the flask and extracted as before. After removal of the supernant, a third extraction was performed and all the screw-capped bottles were subjected to heating at $60^{\circ} \mathrm{C}$. for $1 \mathrm{hr}$. The fluid was then "lightly" spun at 1,500 r.p.m. for $10 \mathrm{~min}$. in order to deposit the gross particles of testicular debris which were subsequently removed. The fluid which contained the Treponema pallidum was then centrifuged for $1 \mathrm{hr}$ at 4,000 r.p.m., thus depositing the organisms in a firm button at the bottom of the tubes. The supernant fluid was decanted, $20 \mathrm{ml}$. of fresh azided saline added to each bottle, and after homogenous suspensions of the organisms made by means of a Wright's pipette, the fluid was centrifuged at 4,000 r.p.m. In all, three such washings were effected and a final suspension of the organisms in not more than 5 $\mathrm{ml}$. of azided saline was transferred from the centrifuge tubes to a sterile $25-\mathrm{ml}$. glass screw-capped bottle. If more than $5 \mathrm{ml}$. of the suspension per $25-\mathrm{ml}$. bottle be used, difficulty in breaking up the organisms may be experienced. Into the bottle was placed enough ground glass* to cover the bottom to a depth of approximately

* The ground glass is made from broken tubes finely ground in a mortar by a pestle, and sieved through one layer of surgical gauze in order to remove the gross particles. It is then treated with bi- 
$\frac{1}{8}$ in. The organisms were then "cut up" by shaking the bottle, secured horizontally on a Kahn shaker, for $1 \mathrm{hr}$ at approximately 280 oscillations per min. At this point it is important to check, by means of a dark-ground examination, that the treponemata have been thoroughly disintegrated. The glass was then allowed to settle (2 min.), and the even suspension which constitutes the antigen was decanted into a sterile bottle.

The antigen should be stored at $4^{\circ} \mathrm{C}$. The strength of the antigen is determined by the method of optimal proportions (Price, 1950a) and is directly proportional to the number of organisms treated, a rough guide being the size of the final "button" obtained immediately before treatment with ground glass. Table I depicts two such titrations, one a weak antigen and the other a much stronger one.

TABLE I

\begin{tabular}{|c|c|c|c|c|c|}
\hline \multirow{2}{*}{ Antigen } & \multicolumn{5}{|c|}{ Positive Serum Dilutions } \\
\hline & $1-8$ & $1-16$ & $1-32$ & $1-64$ & $1-128$ \\
\hline Neat & $=+11$ & & & \pm & - \\
\hline $1-2$ & & 7 & & \pm & - \\
\hline $1-4$ & -+- & \pm & & 一 & - \\
\hline $1-8$ & & & & \pm & \\
\hline & & & & & itre $1-1$ \\
\hline $1-16$ & & & & \pm & \\
\hline $1-32$ & & & \pm & & \\
\hline $1-64$ & & & & & \\
\hline
\end{tabular}

A weak antigen can be strengthened by the simple expedient of adding it to the final button of washed treponemata obtained from another infected rabbit, and, after homogenization, by proceeding to treat the mixture with ground glass as though it were new antigen.

Treponemal antigens for complement-fixation tests when made in the manner described above withstand heating up to $56^{\circ} \mathrm{C}$. for $1 \mathrm{hr}$, and when kept at $4^{\circ} \mathrm{C}$. retain their activity unimpaired for $6 \mathrm{mths}$ and probably longer.

One rabbit will, on average, yield enough treponemata to enable 3 to $5 \mathrm{ml}$. of an antigen of a reasonable titre $(1: 6)$ to be made. Using the technique suggested, this should be sufficient for 900 to 1,400 qualitative tests. It is suggested that in making one batch of antigen six rabbits be employed. The organisms can be extracted from the infected testicles, as and when available, and kept in azided saline at $4^{\circ} \mathrm{C}$. until the operator is ready to proceed with the production of the antigen.

It was shown that uninfected testicles, derived from healthy normal rabbits, fail to yield any treponemal antigenic fraction when subjected to similar processes used in the production of this treponemal antigen.

\section{Results of Parallel Testing}

All sera were tested in parallel with the standard WR as practised in this laboratory (Price, 1950b). If there were any discrepancies in the results, the relevant sera were re-tested and these results taken as final. Amongst the problem sera were those which, as a result of request, were also subjected to a TPI test. Thus, all the sera were unselected and tested in series.

When the clinical notes of the patients whose sera gave discordant results were examined, the patients seemed to fall into five classes:

(1) Patients with a history of, or suffering from, acquired or congenital syphilis.

(2) Patients with a history of, or suffering from, yaws.

(3) Coloured patients coming from areas where yaws is endemic.

(4) Non-treponemal reactors.

(5) Patients who could not be classified owing to inadequate history and/or clinical assessment; this may be due to the patient defaulting or to lack of information.

Whitechapel Clinic (London Hospital) Sera.-In all, 1,030 sera were tested. Of these there were 946 ( 92 per cent.) agreements, of which 94 (9 per cent.) gave positive reactions. There were 84 ( 8 per cent.) disagreements. An examination of the latter is shown in Table II which also demonstrates:

(1) That the treponemal antigen is more sensitive than the standard lipoidal antigen when sera from syphilitic patients are tested.

(2) That the treponemal antigen is more sensitive when sera from patients suffering from yaws are tested.

(3) That the possibility of picking up patients who have had or are suffering from yaws by serum testing is greatly enhanced by the use of the treponemal antigen.

(4) That there is no significant difference in the specificity of either test.

TABLE II

\begin{tabular}{|c|c|c|}
\hline $\begin{array}{c}\text { Clinical } \\
\text { Assessment }\end{array}$ & $\begin{array}{c}\text { Standard WR + } \\
\text { TWR - }\end{array}$ & $\begin{array}{c}\text { Standard WR - } \\
\text { TWR }+\end{array}$ \\
\hline $\begin{array}{crr}\text { Patients suffering } & \text { from } \\
\text { Syphilis } & \ldots & \ldots\end{array}$ & 7 & 25 \\
\hline 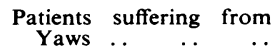 & 0 & 8 \\
\hline $\begin{array}{l}\text { Coloured Patients from } \\
\text { Areas where Yaws is } \\
\text { Endemic } \\
\text {. }\end{array}$ & 1 & 33 \\
\hline Non-treponemal Reactors & 1 & 2 \\
\hline Non-classifiable Patients & 1 & 6 \\
\hline
\end{tabular}

General Hospital (in-patient and out-patient) Sera.A total of 1,205 sera were tested in parallel. Of these 1,171 (97 per cent.) were in agreement, of which 45 (4 per cent.) gave positive reactions. There 
were 34 ( 3 per cent.) discordant results which are set out in Table III.

TABLE III

\begin{tabular}{|c|c|c|}
\hline $\begin{array}{l}\text { Clinical } \\
\text { Assessment }\end{array}$ & $\begin{array}{c}\text { Standard WR } \\
\text { TWR }-\end{array}$ & $\begin{array}{l}\text { Standard WR } \\
\text { TWR }+\end{array}$ \\
\hline $\begin{array}{crr}\begin{array}{c}\text { Patients suffering } \\
\text { Syphilis }\end{array} & \text { from } \\
\end{array}$ & 0 & 7 \\
\hline \begin{tabular}{rrrr} 
Patients & \multicolumn{2}{r}{ suffering } & from \\
Yaws & $\ldots$ & $\ldots$ & $\ldots$
\end{tabular} & 0 & 2 \\
\hline $\begin{array}{l}\text { Coloured Patients from } \\
\text { Areas where Yaws is } \\
\text { Endemic } \\
.\end{array}$ & 0 & 0 \\
\hline Non-treponemal Reactors & 3 & 2 \\
\hline Non-classifiable Patients & 1 & 19 . \\
\hline
\end{tabular}

To a lesser extent this Table shows much the same pattern as Table II, except that, as might be expected, the proportion of unclassified patients is much higher even after vigorous attempts have been made to obtain adequate information.

From this group of sera it was possible to extract the results of the tests on 503 antenatal patients; 495 of these serum tests were in agreement, of which three $(0.6$ per cent.) reacted positively.

Discordant results were obtained with eight sera and the results of these are set out in Table IV which needs no explanation:

TABLE IV

\begin{tabular}{c|c|c}
\hline $\begin{array}{c}\text { Clinical } \\
\text { Assessment }\end{array}$ & $\begin{array}{c}\text { Standard WR } \\
\text { TWR }-\end{array}$ & $\begin{array}{c}\text { Standard WR - } \\
\text { TWR }+\end{array}$ \\
\cline { 2 - 3 } $\begin{array}{c}\text { Patients suffering from } \\
\text { Syphilis }\end{array}$ & 0 & $\cdots$ \\
\hline $\begin{array}{l}\text { Non-treponemal Reactors } \\
\text { Non-classifiable Patients }\end{array}$ & 2 & 3 \\
\hline
\end{tabular}

* One of these subsequently submitted for a TPI test was found to be positive.

Problem Sera.-These are derived from laboratories which have previously found the sera to give anomalous results. A total of 1,044 such sera were tested, and of these 886 ( 85 per cent.) were in agreement, of which 477 (46 per cent.) gave positive reactions. The results of 158 (15 per cent.) differed. An analysis of the disagreements is shown in Table V.

Whilst these sera are unselected, in the sense that they were tested in serial as routine problem sera, it must be remembered that they were selected by the laboratories which sent them in as being sera which had given anomalous results. This may well account for the highlighting of the contrast between the results of testing sera from syphilitic patients and those of testing sera from non-treponemal reactors.
TABLE V

\begin{tabular}{|c|c|c|}
\hline $\begin{array}{c}\text { Clinical } \\
\text { Assessment }\end{array}$ & $\begin{array}{l}\text { Standard WR + } \\
\text { TWR - }\end{array}$ & $\begin{array}{l}\text { Standard WR - } \\
\text { TWR + }\end{array}$ \\
\hline $\begin{array}{crr}\text { Patients suffering } & \text { from } \\
\text { Syphilis } & \ldots & \ldots\end{array}$ & 4 & 87 \\
\hline $\begin{array}{rrrr}\text { Patients } & \text { suffering } & \text { from } \\
\text { Yaws } & . . & . & . \\
\end{array}$ & 0 & 0 \\
\hline $\begin{array}{l}\text { Coloured Patients from } \\
\text { Areas where Yaws is } \\
\text { Endemic } \\
. .\end{array}$ & 0 & 10 \\
\hline Non-treponemal Reactors & 40 & . 10 \\
\hline Non-classifiable Patients & 4 & 3 \\
\hline
\end{tabular}

As many as possible of the problem sera sent into this laboratory are selected for a TPI test, so that the results of parallel testing with the Treponemal WR of 785 sera can be compared. Of these, four sera were reported as resulting in a non-valid test with the TPI test and as anti-complementary with the TWR. Another 31 resulted in a non-valid test with the TPI, whilst the TWR gave definite results. A further fifteen sera were anti-complementary with the TWR but presented no difficulties with the TPI test. Had these latter sera been subjected to the "Titac" (titration of the anti-complementary power of the serum) technique as practised in this laboratory, it is possible that the number of unreportable TWR would have been considerably reduced. However, it is possible to report on the results of 735 sera. Of these, the TPI test and the TWR were in agreement in 670 (91 per cent.), both tests being positive in 350 (48 per cent.). The results obtained with 65 (9 per cent.) disagreed (Table VI).

TABLE VI

\begin{tabular}{|c|c|c|}
\hline $\begin{array}{c}\text { Clinical } \\
\text { Assessment }\end{array}$ & $\begin{array}{l}\text { TPI test + } \\
\text { TWR - }\end{array}$ & $\begin{array}{l}\text { TPI test - } \\
\text { TWR + }\end{array}$ \\
\hline $\begin{array}{crc}\text { Patients suffering } & \text { from } \\
\text { Syphilis } & \cdots & \cdots \\
\end{array}$ & 14 & 16 \\
\hline $\begin{array}{rccc}\text { Patients } & \text { suffering } & \text { from } \\
\text { Yaws } & \cdots & \cdots & \cdots \\
\end{array}$ & 1 & 0 \\
\hline $\begin{array}{ccc}\text { Coloured Patients from } \\
\text { Areas where } & \text { Yaws is } \\
\text { Endemic } & \ldots & \\
\end{array}$ & 1 & 10 \\
\hline Non-treponemal Reactors & 9 & 10 \\
\hline Non-classifiable Patients & 2 & 2 \\
\hline
\end{tabular}

From this Table two facts seem to emerge:

(1) That neither test has any significant advantage over the other as far as sensitivity or specificity is concerned.

(2) The TWR demonstrates serum reactors much more frequently than the TPI when sera from coloured patients are tested. 


\section{Conclusions}

From the data presented there seems to be little doubt that the preparation of the treponemal antigen as previously described should be well within the competence of any reasonably equipped laboratory. The antigen is stable and the amount obtained per rabbit is economic.

The results of testing sera show that the reactions obtained are reproducible when using this antigen and are more sensitive and specific than those obtained when the standard lipoidal WR antigen is employed. Sera tested in parallel with the TPI test show that neither test has any significant advantage over the other in specifirity or sensitivity. The technical advantages of the TWR as compared with the TPI test are so great that they cannot lightly be dismissed.

The significance of the results obtained when testing sera from coloured patients has yet to be demonsirated. This paper is concerned with routine groups of sera tested in this laboratory. More work is required on selected sera, particularly those coming from coloured patients and those which are well known to be liable to give positive non-treponemal reactions. Nevertheless, the results obtained so far give rise to a strong hope that this specific test will soon be a practical procedure for the routine serological diagnosis or exclusion of treponemal infections.

Our thanks are due to Dr. A. E. Wilkinson who carried out the TPI tests.

\section{REFERENCES}

Magnuson, H. J., and Portnoy, J. (1956). Amer. J. publ. Hlth, 46, 190.

Portnoy, J., and Magnuson, H. J. (1955). J. Immunol., 75, 348.

(1956). Amer. J. clin. Path., 26, 313.

Price, I. N. O. (1949). British Journal of Venereal Diseases, 25, 157. (1950 a). Ibid, 26, 33.

(1950 b). Ibid., 27, 172,

Tuttle, R. L., and DeBerry, P. (1955). American Naval Medical Research Institute. Report NM 005 048.17.02., vol. 13, p. 759. 